\title{
Selection of strains for shiitake production in axenic substrate
}

\author{
Diego Cunha Zied ${ }^{1}$ William Pereira Maciel $^{2} \cdot$ Simone Cristina Marques $^{2} \cdot$ \\ Débora Marques da Silveira e Santos ${ }^{2} \cdot$ Danny Lee Rinker $^{3} \cdot$ Eustáquio Souza Dias $^{2}$
}

Received: 10 November 2015/Accepted: 21 July 2016/Published online: 26 August 2016

(C) Springer Science+Business Media Dordrecht 2016

\begin{abstract}
Shiitake mushroom consumption is increasing in Brazil. In addition to the implementation of new production methods, it is also important to increase productivity, quality and reduce production costs. In this study, six commercial Lentinula edodes strains were characterized for genetic diversity (rep-PCR analysis) and mushroom production (yield, number and weight of individual mushrooms) using different substrates and cultural conditions. All strains showed genetic differences by repetitive element palindromic based-polymerase chain reaction (rep$\mathrm{PCR})$. The richest substrate resulted in the greatest production under both environmental conditions. Strains LE4 and LE6 produced the majority of their mushrooms earlier than the other strains. The highest number of mushrooms was observed in the LE6 strain while the highest weights of individual mushrooms were observed in the LE4 strain. Controlled environmental conditions resulted in superior production for all strains, except for LE4, which had empirically greater yield in the semi-controlled environmental condition.
\end{abstract}

Keywords Lentinula edodes - Genetic diversity · Mushroom yield $\cdot$ Strain selection

Diego Cunha Zied

dczied@gmail.com

1 Faculdade de Ciências Agrárias e Tecnológicas (FCAT), Universidade Estadual Paulista (UNESP), Dracena, SP, Brazil

2 Departamento de Biologia, Universidade Federal de Lavras (UFLA), PO Box 3037, Lavras, MG 37200-000, Brazil

3 Department of Plant Agriculture, University of Guelph, Guelph, ON, Canada

\section{Introduction}

Lentinula edodes (Berkeley) Pegler, known as shiitake, is the second most cultivated edible mushroom worldwide, representing $25 \%$ of the world mushroom production (Nikita et al. 2007; Jiang et al. 2010). However, to improve this mushroom production in developing countries, it is necessary to reduce its production costs by developing new technologies for mushroom cultivation and breeding. The strain selection for commercial cultivation and breeding is an important step to identify strains that are productive, and adapted to conditions of tropical countries. Therefore, it is important to analyze the genetic diversity and mushroom production and to identify potential parental strains. Different strains may differ in mycelial growth rate, spawnrun, cultivation temperature and nutritional requirements (Mata and Savoie 1998; Royse and Sanchez-Vazquez 2001; Gbolagade et al. 2006).

Different agricultural residues may be used as alternative substrates for mushroom cultivation (Philippoussis et al. 2007); however, the substrate most traditionally used is oak sawdust (Zervakis et al. 2001). In Brazil, the best option is Eucalyptus sawdust because it is widely available from the wood industry. Nevertheless, there have been no conclusive studies regarding the ideal formulation of this substrate and its interaction with different strains and environmental cultivation conditions.

Strains may behave differently under various conditions of cultivation. Developing countries are not always equipped with rigidly controlled environmental cultivation facilities. Therefore, more strains should be selected for production in facilities where environmental conditions are semi-controlled or where there is little control over cultivation environment. In this study, six commercial $L$. edodes strains were characterized for genetic diversity and 
mushroom production using different substrates and under different cultivation environments.

\section{Materials and methods}

\section{rep-PCR analysis}

Five mycelial discs of each strain were inoculated in flasks containing $100 \mathrm{~mL}$ of potato dextrose broth, with five replicates for each. The flasks were incubated at $160 \mathrm{rpm}$ at $25^{\circ} \mathrm{C}$ for 15 days to obtain the mycelial mass. DNA extraction was performed according to Edwards et al. (1991) with modifications. The mycelium was filtered, washed with distilled water and macerated with a porcelain mortar and pestle using liquid nitrogen until a fine powder was obtained. The samples $(200 \mathrm{mg}$ ) were transferred to micro tubes with $600 \mu \mathrm{L}$ extraction buffer $(50 \mathrm{mM}$ Tris$\mathrm{HCl} \mathrm{pH}=8,20 \mathrm{mM}$ EDTA $\mathrm{pH}=7.5$ and $1 \%$ SDS). After agitation with a vortex, the microtubes were incubated in a $60{ }^{\circ} \mathrm{C}$ bath for $30 \mathrm{~min}$. After adding $500 \mu \mathrm{L}$ buffered phenol $(0.1 \%$ hydroxyquinoline and $0.1 \mathrm{M}$ Tris$\mathrm{HCl} \mathrm{pH} \mathrm{=8.0),} \mathrm{the} \mathrm{mixture} \mathrm{was} \mathrm{slowly} \mathrm{homogenized} \mathrm{for}$ approximately $10 \mathrm{~min}$, and stored in ice. The microtubes were centrifuged for $15 \mathrm{~min}$ at $12,000 \mathrm{rpm}$, and the supernatant was transferred to a new microtube containing $500 \mu \mathrm{L}$ phenol/chloroform and incubated on ice for the deproteination process for $20 \mathrm{~min}$. The third stage of deproteination was performed with chloroform for $10 \mathrm{~min}$ on ice, followed by a centrifugation for $15 \mathrm{~min}$ at $12,000 \mathrm{rpm}$. This supernatant was transferred to a new microtube. DNA was precipitated using $200 \mathrm{mM} \mathrm{NaCl}$ and one volume of isopropanol for $30 \mathrm{~min}$ in the freezer. After DNA precipitation, the mixture was centrifuged for $20 \mathrm{~min}$ at 13,400 rpm. The supernatant was decanted and the pellet washed with $100 \mu \mathrm{L} 70 \%$ ethanol and dried at ambient temperature. Finally, the DNA was resuspended in $50 \mu \mathrm{L}$ of TE (10 mM Tris-HCl and $1 \mathrm{mM}$ EDTA 1$)$.

The PCR reactions were carried out in a final volume of $25 \mu \mathrm{L}$ containing $1.5 \mu \mathrm{L}$ DNA, $2.5 \mu \mathrm{L}$ buffer, $1.0 \mu \mathrm{L}$ $\mathrm{MgCl}_{2}, 1.0 \mu \mathrm{L}$ dNTP, $2.0 \mu \mathrm{L}$ primer GTG $_{5}\left(5^{\prime}-\mathrm{GTG}\right.$ GTG GTG GTG GTG-3'), $0.3 \mu \mathrm{L}$ Taq DNA polymerase, $0.25 \mu \mathrm{L}$ formamide, and $0.25 \mu \mathrm{L}$ BSA. Amplification was achieved using a Master Gradient Eppendorf Thermal Cycler (Eppendorf, Germany). The cycling conditions were as follows: initial denaturation cycle of $5 \mathrm{~min}$ at $94{ }^{\circ} \mathrm{C}$, followed by 30 cycles of $95^{\circ} \mathrm{C}$ for $30 \mathrm{~s}, 45^{\circ} \mathrm{C}$ for $60 \mathrm{~s}$ and $60{ }^{\circ} \mathrm{C}$ for $5 \mathrm{~min}$, and a final extension at $60{ }^{\circ} \mathrm{C}$ for $16 \mathrm{~min}$.

The PCR products were electrophoresed in $1.5 \%$ agarose (Sigma-Aldrich Co., St Louis, USA) in TAE $1 \mathrm{X}$ buffer at $100 \mathrm{~V}$ for $6 \mathrm{~h}$, stained with ethidium bromide and visualized with a transilluminator (LTB $20 \times 20 \mathrm{HE}$, LPix $^{\circledR}$, Brazil). The rep-PCR profiles were subjected to grouping analysis using the Bionumerics 2.50 software (Applied Maths, Sint-Martens-Latem, Belgium).

\section{Spawn production}

Six strains of L. edodes LE1 to LE6 were evaluated. The strains were cultured on PDA medium (potato dextrose agar) at $25{ }^{\circ} \mathrm{C}$ in preparation for inoculation of the substrate for spawn. For spawn production, sawdust of Eucalyptus was supplemented with $10 \%$ wheat bran, $2 \%$ gypsum and $2 \%$ limestone. The ingredients were thoroughly mixed, and the moisture adjusted to $60 \%$. This mixture (400 g) was added to a flask and autoclaved for $2 \mathrm{~h}$ at $121{ }^{\circ} \mathrm{C}$. After the substrate cooled to room temperature, four discs of mycelium ( $5 \mathrm{~mm}$ diameter), previously prepared on PDA medium, were added to the substrate in each flask. These units were incubated at room temperature $\left(24-28^{\circ} \mathrm{C}\right)$ for 3 weeks.

\section{Substrate preparation}

Three different substrates were evaluated: Substrate 1$80 \%$ Eucalyptus sawdust (SW) and $20 \%$ wheat bran (WB), (0.96\% total nitrogen content with $7.0 \mathrm{pH})$; Substrate 2-90\% SW, $1 \% \mathrm{WB}, 1 \%$ cottonseed meal (CM), $1 \%$ coarse cornmeal (CC), $6.8 \%$ rice bran $(\mathrm{RB})$ and $0.2 \% \mathrm{CaCO}_{3}(1.06 \%$ total nitrogen content with $6.7 \mathrm{pH})$; Substrate 3-80\% SW, $2 \% \mathrm{WB}, 2 \% \mathrm{CM}, 2 \% \mathrm{CC}$, $13.6 \% \mathrm{RB}$ and $0.4 \% \mathrm{CaCO}_{3}(1.18 \%$ total nitrogen content with $6.8 \mathrm{pH})$. Each substrate $(2.5 \mathrm{~kg})$ was placed in a high density polypropylene bag fitted with a $4 \mathrm{~cm}^{2}$ filter. The bags were sealed and autoclaved at $121^{\circ} \mathrm{C}$ for $2 \mathrm{~h}$. The autoclaving process was repeated after $24 \mathrm{~h}$. After cooling to room temperature, the substrates were inoculated with $75 \mathrm{~g}$ spawn per bag and incubated at room temperature $\left(24-28{ }^{\circ} \mathrm{C}\right)$ for the colonization and browning process. After 2 months of incubation, the bags were opened to facilitate the browning process and to permit further air circulation for an additional month. After that additional time, the plastic was completely removed, leaving a browned substrate, hereafter referred to as "block".

\section{Pining and cultivation}

L. edodes production was evaluated under two environmental conditions: Experiment 1-in a facility with no temperature control, which ranged from $14 \pm 2{ }^{\circ} \mathrm{C}$ (night) to $22 \pm 3{ }^{\circ} \mathrm{C}$ (day); Experiment 2-in a facility with controlled temperature, which was maintained at $16 \pm 2{ }^{\circ} \mathrm{C}$. In both facilities, the relative humidity was above $80 \%$, and the $\mathrm{CO}_{2}$ concentration was below $1000 \mathrm{ppm}$, during the entire cultivation cycle. When the 
browning process was complete, 3 months after inoculation, blocks were transported to the mushroom cultivation facilities. Throughout the entire cultivation period, the blocks and mushrooms were maintained in light. The first flush occurred for 30 days, and after this period, the temperature of the controlled facility was raised to $25{ }^{\circ} \mathrm{C}$ for 10 days. In order to initiate the second flush, the blocks from both experiments were immersed in $14{ }^{\circ} \mathrm{C}$ water for $8 \mathrm{~h}$, and then cultivated again under their previous conditions.

\section{Mushroom production}

Mushrooms were harvested with gills exposed and the margin of the pileus slightly turned under. Untrimmed mushrooms were counted per unit and weighed daily. Yield for each flush and total was converted to fresh weight biological efficiency (fresh weight of mushrooms divided by the fresh weight of substrate multiplied by 100); the number of mushrooms was represented by harvested mushroom count per $2.5 \mathrm{~kg}$ of substrate; and the average weight per mushroom was calculated by the fresh weight of mushrooms per block divided by the number of mushrooms according to Dias et al. (2013).

\section{Statistical analysis}

Both experiments followed a $6 \times 3$ factorial design $(6$ shiitake strains by 3 substrate compositions) with 10 replications for each treatment. Each replication corresponded to each polypropylene bag filled with $2.5 \mathrm{~kg}$ of substrate. Statgraphics Plus v. 4.1 (Statistical Graphics Corp., Princeton, NJ, USA) was used to analyze yield (1st flush, 2nd flush and total yield), number and individual mushroom weight. Means were separated at the $5 \%$ level according to the Tukey-Honest Significance Different test.

\section{Results}

\section{Genetic diversity of $L$. edodes strains}

The L. edodes strains were grouped into two main clusters, with similarity coefficients ranging from 0.72 to 1.00 (Fig. 1). The largest cluster comprised 5 strains, with only one in the second cluster. Greater genetic similarity was observed for strains LE3 and LE4 (94\%). Strain LE1 had less genetic similarity (72\%) to the other strains.

\section{Mushroom production}

Both main effects, strain and substrate composition, significantly $(p<0.0001)$ influenced shiitake yield for 1 st

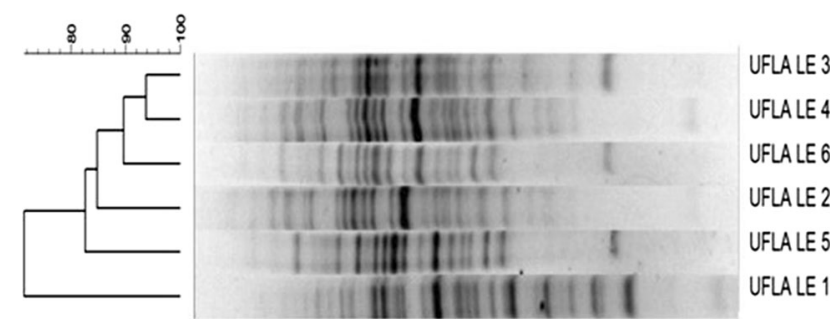

Fig. 1 Dendrogram of genetic similarity and pattern of bands obtained in the analysis of rep-PCR strain of L. edodes

flush, 2nd flush and total yield in both environments (ANOVA table not shown). Average substrate yields regardless of strain were significantly different one from the other; and average yields across all strains regardless of substrate were nearly all significantly different from each other as well (Table 1). Substrate 3 was the superior substrate composition across all strains for both environments. The top two producing strains for the controlled environment were LE2 and 6; whereas, for the semi-controlled environment LE4 and 6 were statistically the same, followed similarly by LE2 and 3. There were significant interactions between strains and substrates for both environments. Thus, the yield response is not independent of strain or substrate but requiring the correct combination of the two for optimum production.

Strain LE5 did not produce mushrooms because the browning process did not occur, despite all substrates being colonized by this strain. This is not uncommon where colonization is good but production is non-existent (Rinker 1991).

The majority of total yield was harvested in the $1^{\text {st }}$ flush for the strains LE4 and LE6 under controlled environmental conditions, while the other strains produced the majority of their total yield in the 2nd flush. In the semicontrolled environment this difference existed but not to the same degree.

The numbers of mushrooms were significantly $(p<0.0001)$ affected by strain and substrate composition under both environmental conditions (ANOVA table not shown). Average numbers of mushrooms for each substrate regardless of strain were significantly different one from the other; and the mushroom numbers for each strain across all substrates were nearly all significantly different from each other (Table 2). The response of mushroom numbers to the interaction of strain and substrate composition was significant and thus not independent of one another.

Strain LE6 developed the greatest number of mushrooms in both environments. Strain LE4 had the least number of mushrooms in the controlled environmental conditions, while LE2 had the fewest number in the semicontrolled environmental conditions.

The substrate composition did not significantly affect individual mushroom weight in either environment. 
Table 1 Average yield in terms of biological efficiency [(mushroom weight/substrate wet weight $) \times 100]$ from six strains of Lentinula. edodes cultivated on three substrate compositions, under two environmental conditions

\begin{tabular}{|c|c|c|c|c|c|c|c|c|c|c|c|c|}
\hline \multirow[t]{2}{*}{ Strain\substrate } & \multicolumn{3}{|c|}{ 1st flush yield } & \multicolumn{5}{|c|}{ 2nd flush yield } & \multicolumn{4}{|c|}{ Total yield } \\
\hline & $1 * *$ & 2 & 3 & $\begin{array}{l}\text { 1st flush } \\
\text { strain } \\
\text { average }\end{array}$ & 1 & 2 & 3 & $\begin{array}{l}\text { 2nd flush } \\
\text { strain } \\
\text { average }\end{array}$ & 1 & 2 & 3 & $\begin{array}{l}\text { Strain } \\
\text { average }\end{array}$ \\
\hline \multicolumn{13}{|c|}{ Controlled environmental conditions } \\
\hline LE $1 *$ & $5.2^{\mathrm{c} \mathrm{D}}$ & $8.6^{\mathrm{b} \mathrm{D}}$ & $10.6^{\mathrm{a} \mathrm{D}}$ & $8.2^{\mathrm{D}}$ & $8.0^{\mathrm{b} \mathrm{AB}}$ & $12.5^{\mathrm{a} \mathrm{A}}$ & $12.7^{\mathrm{a} \mathrm{A}}$ & $11.1^{\mathrm{A}}$ & $13.3^{\mathrm{c} \mathrm{C}}$ & $21.1^{\mathrm{b} \mathrm{B}}$ & $23.4^{\mathrm{a} \mathrm{AB}}$ & $19.3^{\mathrm{C}}$ \\
\hline LE 2 & $6.8^{\mathrm{c} \mathrm{C}}$ & $10.9^{\mathrm{b} \mathrm{C}}$ & $12.4^{\mathrm{a} \mathrm{C}}$ & $10.1^{\mathrm{C}}$ & $9.2^{\mathrm{b} \mathrm{A}}$ & $12.8^{\mathrm{a} \mathrm{A}}$ & $11.4^{\mathrm{a} \mathrm{A}}$ & $11.1^{\mathrm{A}}$ & $16.1^{\mathrm{b} \mathrm{B}}$ & $23.7^{\mathrm{a} \mathrm{A}}$ & $23.8^{\mathrm{a} \mathrm{AB}}$ & $21.2^{\mathrm{B}}$ \\
\hline LE 3 & $5.6^{\mathrm{c} \mathrm{D}}$ & $9.1^{\mathrm{b} \mathrm{D}}$ & $11.0^{\mathrm{a} D}$ & $8.6^{\mathrm{D}}$ & $8.8^{\mathrm{b} \mathrm{A}}$ & $10.0^{\mathrm{b} \mathrm{B}}$ & $11.6^{\mathrm{a} \mathrm{A}}$ & $10.3^{\mathrm{A}}$ & $14.4^{\mathrm{c} \mathrm{BC}}$ & $19.1^{\mathrm{b} \mathrm{C}}$ & $22.7^{\mathrm{a} \mathrm{B}}$ & $18.8^{\mathrm{C}}$ \\
\hline LE 4 & $8.8^{\mathrm{c} \mathrm{B}}$ & $14.7^{\mathrm{b} \mathrm{B}}$ & $16.3^{\mathrm{a} \mathrm{B}}$ & $13.3^{\mathrm{B}}$ & $6.8^{\mathrm{a} \mathrm{B}}$ & $5.3^{\mathrm{b} \mathrm{C}}$ & $5.8^{\mathrm{ab} \mathrm{B}}$ & $6.0^{\mathrm{C}}$ & $15.6^{\mathrm{c} \mathrm{B}}$ & $20.0^{\mathrm{b} \mathrm{BC}}$ & $22.2^{\mathrm{a} \mathrm{B}}$ & $19.3^{\mathrm{C}}$ \\
\hline LE 6 & $11.8^{\mathrm{c} \mathrm{A}}$ & $16.6^{\mathrm{b} \mathrm{A}}$ & $17.7^{\mathrm{a} A}$ & $15.4^{\mathrm{A}}$ & $8.4^{\mathrm{a} \mathrm{AB}}$ & $6.5^{\mathrm{b} \mathrm{c}}$ & $6.9^{\mathrm{b} \mathrm{B}}$ & $7.3^{\mathrm{B}}$ & $20.3^{\mathrm{b} \mathrm{A}}$ & $23.2^{\mathrm{a}} \mathrm{A}$ & $24.6^{\mathrm{a} A}$ & $22.7^{\mathrm{A}}$ \\
\hline $\begin{array}{r}\text { Substrate } \\
\text { average }\end{array}$ & $7.7^{\mathrm{c}}$ & $12.0^{\mathrm{b}}$ & $13.6^{\mathrm{a}}$ & & $8.3^{\mathrm{b}}$ & $9.4^{\mathrm{a}}$ & $9.7^{\mathrm{a}}$ & & $15.9^{\mathrm{c}}$ & $21.4^{\mathrm{b}}$ & $23.3^{\mathrm{a}}$ & \\
\hline \multirow[t]{2}{*}{ Strain\substrate } & \multicolumn{3}{|c|}{ 1st flush yield } & \multicolumn{5}{|c|}{ 2nd flush yield } & \multicolumn{4}{|c|}{ Total yield } \\
\hline & 1 & 2 & $\begin{array}{l}\text { Strain } \\
\text { average }\end{array}$ & $\begin{array}{l}\text { 1st flush } \\
\text { strain } \\
\text { average }\end{array}$ & 1 & 2 & 3 & $\begin{array}{l}\text { 2nd flush } \\
\text { strain } \\
\text { average }\end{array}$ & 1 & 2 & 3 & $\begin{array}{l}\text { Strain } \\
\text { average }\end{array}$ \\
\hline \multicolumn{13}{|c|}{ Semi-controlled environmental conditions } \\
\hline LE 1 & $3.9^{\mathrm{b} \mathrm{C}}$ & $6.9^{\mathrm{a} \mathrm{B}}$ & $8.1^{\text {a B }}$ & $6.3^{\mathrm{C}}$ & $5.4^{\mathrm{c} \mathrm{C}}$ & $7.9^{\mathrm{b} \mathrm{C}}$ & $9.0^{\mathrm{a} \mathrm{C}}$ & $7.4^{\mathrm{C}}$ & $9.3^{\mathrm{c} \mathrm{C}}$ & $14.8^{\mathrm{b} \mathrm{C}}$ & $17.2^{\mathrm{a} C D}$ & $13.8^{\mathrm{C}}$ \\
\hline LE 2 & $5.6^{\mathrm{b} \mathrm{BC}}$ & $7.7^{\mathrm{a} \mathrm{B}}$ & $7.0^{\mathrm{ab} \mathrm{B}}$ & $6.8^{\mathrm{C}}$ & $7.9^{\mathrm{b}} \mathrm{AB}$ & $9.2^{\mathrm{a} \mathrm{B}}$ & $9.3^{\mathrm{a} B C}$ & $8.6^{\mathrm{B}}$ & $13.6^{\mathrm{b} \mathrm{B}}$ & $17.0^{\mathrm{a} \mathrm{B}}$ & $16.4^{\mathrm{a} D}$ & $15.6^{\mathrm{B}}$ \\
\hline LE 3 & $4.4^{\mathrm{b} \mathrm{C}}$ & $7.9^{\mathrm{a} \mathrm{B}}$ & $8.3^{\mathrm{a} \mathrm{B}}$ & $6.9^{\mathrm{C}}$ & $7.4^{\mathrm{b} \mathrm{AB}}$ & $10.0^{\mathrm{a} \mathrm{B}}$ & $10.2^{\mathrm{a} \mathrm{AB}}$ & $9.2^{\mathrm{AB}}$ & $11.8^{\mathrm{b} \mathrm{B}}$ & $18.0^{\mathrm{a} B}$ & $18.6^{\mathrm{a} \mathrm{C}}$ & $16.1^{\mathrm{B}}$ \\
\hline LE 4 & $6.6^{\mathrm{c} \mathrm{B}}$ & $10.8^{\mathrm{b} \mathrm{A}}$ & $13.6^{\mathrm{a} \mathrm{A}}$ & $10.3^{\mathrm{B}}$ & $7.0^{\mathrm{b} \mathrm{B}}$ & $11.3^{\mathrm{a} \mathrm{A}}$ & $11.3^{\mathrm{a} \mathrm{A}}$ & $9.8^{\mathrm{A}}$ & $13.6^{\mathrm{c} \mathrm{B}}$ & $22.1^{\mathrm{b} \mathrm{A}}$ & $24.9^{\mathrm{a} \mathrm{A}}$ & $20.0^{\mathrm{A}}$ \\
\hline LE 6 & $9.9^{\mathrm{b} \mathrm{A}}$ & $11.0^{\mathrm{b} \mathrm{A}}$ & $14.3^{\mathrm{a} \mathrm{A}}$ & $11.7^{\mathrm{A}}$ & $8.5^{\mathrm{b} \mathrm{A}}$ & $9.7^{\mathrm{a} \mathrm{B}}$ & $8.4^{\mathrm{b} \mathrm{C}}$ & $8.9^{\mathrm{B}}$ & $18.4^{\mathrm{c} \mathrm{A}}$ & $20.7^{\mathrm{b} \mathrm{A}}$ & $22.8^{\mathrm{a} B}$ & $20.6^{\mathrm{A}}$ \\
\hline $\begin{array}{r}\text { Substrate } \\
\text { average }\end{array}$ & $6.1^{\mathrm{c}}$ & $8.9^{\mathrm{b}}$ & $10.3^{\mathrm{a}}$ & & $7.2^{\mathrm{b}}$ & $9.6^{\mathrm{a}}$ & $9.6^{\mathrm{a}}$ & & $13.3^{\mathrm{c}}$ & $18.5^{\mathrm{b}}$ & $20.0^{\mathrm{a}}$ & \\
\hline
\end{tabular}

* Means in the same row within flush, total yield or strain mean followed by the same lowercase letter are not significantly different at $5 \%$ level according to Tukey's honest significance test

** Similarly, means in the same column within an environment followed by the same uppercase letter are not significantly different at $5 \%$ level according to Tukey's honest significance test

However, the individual mushroom weight was significantly affected by strain. In both environments nearly each strain was significantly different from the other. Rankings of mushroom weight among strains were the same for both environments with strain LE4 producing the heaviest mushrooms for both. Mushroom weight was independent of strain and substrate combination for the controlled environment and the interaction between strain and substrate was almost not significant $(p=0.047)$ for semicontrolled conditions.

\section{Discussion}

\section{Genetic diversity of $L$. edodes strains}

For a breeding program approach, the high similarity shared by $L$. edodes strains suggests that it is necessary to introduce others sources of breeding material (Zhang et al.
2010). Yet, all the evaluated strains showed polymorphic bands, indicating some genetic diversity and lack of duplication in our collection. These genetic differences may also be expressed in different phenotypic traits, such as enzyme activity and mushroom yield, making it possible to select some strains as potential parents for a future breeding program. These new hybrids could be more appropriate for the growth conditions in Brazil. In the present research it was not possible to associate the genetic differences of the strains with mushroom production (yield, number and individual mushroom weight).

\section{Mushroom production}

Successful mushroom production is dependent on many factors. The selection of substrate composition, mushroom strain and the cultural conditions are normally under the management of the producer. This study has demonstrated that mushroom yield, numbers and individual mushroom 
Table 2 Mean number and average weight $(\mathrm{g})$ of individual mushrooms from six strains of Lentinula edodes cultivated on three different substrate compositions, under two environmental conditions

\begin{tabular}{|c|c|c|c|c|c|c|c|c|}
\hline \multirow[t]{2}{*}{ Strainlsubstrate } & \multicolumn{4}{|c|}{ Number of mushrooms } & \multicolumn{4}{|c|}{ Weight of individual mushroom } \\
\hline & $1 * *$ & 2 & 3 & Number strain average & 1 & 2 & 3 & Weight strain Average \\
\hline \multicolumn{9}{|c|}{ Controlled environmental conditions } \\
\hline LE $1 *$ & $11.0^{\mathrm{c} \mathrm{C}}$ & $17.8^{\mathrm{b} \mathrm{B}}$ & $19.6^{\mathrm{a} \mathrm{B}}$ & $16.1^{\mathrm{B}}$ & $30.2^{\mathrm{a} \mathrm{C}}$ & $29.6^{\mathrm{a} C}$ & $29.8^{\mathrm{a} \mathrm{C}}$ & $29.9^{\mathrm{C}}$ \\
\hline LE 2 & $10.0^{\mathrm{c} \mathrm{D}}$ & $14.0^{\mathrm{b} \mathrm{D}}$ & $15.0^{\mathrm{a} \mathrm{C}}$ & $13.0^{\mathrm{C}}$ & $40.2^{\mathrm{b} \mathrm{B}}$ & $42.5^{\mathrm{a} \mathrm{B}}$ & $39.9^{\mathrm{b} \mathrm{B}}$ & $40.9^{\mathrm{B}}$ \\
\hline LE 3 & $12.0^{\mathrm{c} \mathrm{B}}$ & $15.8^{\mathrm{b} \mathrm{C}}$ & $19.0^{\mathrm{a} B}$ & $15.6^{\mathrm{B}}$ & $30.1^{\mathrm{a} \mathrm{C}}$ & $30.2^{\mathrm{a} C}$ & $29.9^{\mathrm{a} C}$ & $30.1^{\mathrm{C}}$ \\
\hline LE 4 & $7.7^{\mathrm{c} \mathrm{E}}$ & $10.0^{\mathrm{b} \mathrm{E}}$ & $11.1^{\mathrm{a} \mathrm{D}}$ & $9.6^{\mathrm{D}}$ & $50.4^{\mathrm{a} \mathrm{A}}$ & $50.2^{\mathrm{a} \mathrm{A}}$ & $50.3^{\mathrm{a} \mathrm{A}}$ & $50.3^{\mathrm{A}}$ \\
\hline LE 6 & $25.2^{\mathrm{c} \mathrm{A}}$ & $29.1^{\mathrm{b} \mathrm{A}}$ & $31.0^{\mathrm{a} \mathrm{A}}$ & $28.4^{\mathrm{A}}$ & $20.2^{\mathrm{a} \mathrm{D}}$ & $19.8^{\mathrm{a} \mathrm{D}}$ & $19.9^{\mathrm{a} D}$ & $19.9^{\mathrm{D}}$ \\
\hline Substrate average & $13.2^{\mathrm{c}}$ & $17.3^{\mathrm{b}}$ & $19.1^{\mathrm{a}}$ & & $34.2^{\mathrm{a}}$ & $34.5^{\mathrm{a}}$ & $34.0^{\mathrm{a}}$ & \\
\hline \multirow[t]{2}{*}{ Strainlsubstrate } & \multicolumn{4}{|c|}{ Number of mushrooms } & \multicolumn{4}{|c|}{ Weight of individual mushroom } \\
\hline & 1 & 2 & 3 & Number strain average & 1 & 2 & 3 & Weight strain average \\
\hline \multicolumn{9}{|c|}{ Semi-controlled environmental conditions } \\
\hline LE 1 & $8.2^{\mathrm{c} \mathrm{C}}$ & $12.3^{\mathrm{b} \mathrm{C}}$ & $14.6^{\mathrm{a} \mathrm{C}}$ & $11.7^{\mathrm{C}}$ & $28.5^{\mathrm{a} \mathrm{C}}$ & $29.9^{\mathrm{a} B}$ & $29.4^{\mathrm{a} \mathrm{C}}$ & $29.3^{\mathrm{C}}$ \\
\hline LE 2 & $8.0^{\mathrm{b} \mathrm{C}}$ & $9.1^{\mathrm{a} E}$ & $9.1^{\mathrm{a} \mathrm{E}}$ & $8.7^{\mathrm{E}}$ & $42.4^{\mathrm{b} \mathrm{B}}$ & $46.6^{\mathrm{a} \mathrm{A}}$ & $45.3^{\mathrm{ab} \mathrm{B}}$ & $44.8^{\mathrm{B}}$ \\
\hline LE 3 & $9.5^{\mathrm{b} \mathrm{B}}$ & $15.3^{\mathrm{a} \mathrm{B}}$ & $15.7^{\mathrm{a} \mathrm{B}}$ & $13.5^{\mathrm{B}}$ & $30.9^{\text {a C }}$ & $29.3^{\mathrm{a} \mathrm{B}}$ & $29.5^{\mathrm{a} \mathrm{C}}$ & $29.6^{\mathrm{C}}$ \\
\hline LE 4 & $6.7^{\mathrm{c} \mathrm{D}}$ & $11.1^{\mathrm{b} \mathrm{D}}$ & $12.6^{\mathrm{a} \mathrm{D}}$ & $10.1^{\mathrm{D}}$ & $50.8^{\mathrm{a} \mathrm{A}}$ & $49.7^{\mathrm{a} \mathrm{A}}$ & $49.3^{\mathrm{a} \mathrm{A}}$ & $50.0^{\mathrm{A}}$ \\
\hline LE 6 & $22.8^{\mathrm{b} \mathrm{A}}$ & $27.8^{\mathrm{a} \mathrm{A}}$ & $28.0^{\mathrm{a} A}$ & $26.2^{\mathrm{A}}$ & $20.1^{\mathrm{a} \mathrm{D}}$ & $18.7^{\mathrm{a} \mathrm{C}}$ & $20.2^{\mathrm{a} \mathrm{D}}$ & $19.7^{\mathrm{D}}$ \\
\hline Substrate average & $11.0^{\mathrm{c}}$ & $15.1^{\mathrm{b}}$ & $16.0^{\mathrm{a}}$ & & $34.6^{\mathrm{a}}$ & $34.9^{\mathrm{a}}$ & $34.7^{\mathrm{a}}$ & \\
\hline
\end{tabular}

* Means in the same row within flush, total yield or strain mean followed by the same lowercase letter are not significantly different at $5 \%$ level according to Tukey's honest significance test

** Similarly, means in the same column within an environment followed by the same uppercase letter are not significantly different at $5 \%$ level according to Tukey's honest significance test

weights are dependent on strain using substrates available in Brazil. Differences among strains are not novel (Rinker, 1991). However, production data utilizing the substrates and conditions of Brazil are important for the selection of appropriate strains for production and in the development of a breeding program.

Our strains demonstrated a more uniform mushroom yield under controlled environmental conditions than under semi-controlled conditions, with a biological efficiency range of 3.9 and $6.8 \%$, respectively (Table 1). The narrower range under the controlled environmental conditions affirmed the strong influence of the environment on the phenotype where there is low genetic diversity. Management of temperature was essential, for the majority of strains, to maximize mushroom yields. At the same time, it is possible to use a simpler mushroom facility, if an appropriate strain is used (LE4 or LE6) and the natural variations of environmental conditions match the limits for the species. According to Zervakis et al. (2001), L. edodes can grow at different temperatures because each strain has an optimum growing temperature. However, Bruhn and Mihail (2009) reported that a controlled temperature environment allows greater biological efficiency and more uniform shiitake mushroom size.
The size or weight of individual mushrooms is an important characteristic for the market and harvest efficiency. Typically, larger mushrooms are desirable over smaller ones and more rapidly harvested. Strain LE4 produced well under both environments, with fewer mushrooms of higher individual weight. Although LE6 was a very good producer in total yield, its mushrooms were numerous and small. LE2 yielded few mushrooms of high individual weight, but the total yield was completely different between the different environments. Mushroom size is dependent on strain but not substrate composition and is independent of facility type.

Mushroom yield is more complicated since it is dependent on strain, substrate composition and the combination of the two. More complex substrates and higher total $\mathrm{N}$ (substrates 2 and 3 ) resulted in higher mushroom production but no difference in individual mushroom weights. Overall for both environments, the richer the substrate was in nitrogen the greater was the mushroom yield. Boyle (1998) studied the nutritional factors that limited the growth of 2 strains of shiitake. The author verified that the strains differed in their responses to $\mathrm{N}$ sources. Zied et al. (2011) reported that supplementation of substrate with soybean based products is common in the 
mushroom cultivation and the yields generally increase 5-20\%, and occasionally by more.

Others minerals such as magnesium, calcium, iron, copper, manganese, zinc and, often molybdenum, are required by fungi for growth (Jennings 1995); and these are present in wheat bran, coarse cornmeal and rice bran. Royse and Sanchez-Vazquez (2003) verified that yields and biological efficiencies from substrates that were not supplemented with $\mathrm{CaCO}_{3}$ were lower by 14.1, 18.4 and $24.9 \%$ compared to treatments supplemented with $0.2,0.4$ and $0.6 \% \mathrm{CaCO}_{3}$, respectively. However, mushroom size (weight) was larger with non-supplemented substrate compared to substrate supplemented with $\mathrm{CaCO}_{3}$ (Royse and Sanchez-Vazquez 2003).

A strain selected for a breeding program would be expected to perform consistently for similar substrates in various environments. These differences are an evidence of interesting genetic variances between the strains that the rep-PCR technique did not show. Thus, other PCR techniques will need to be explored in order to study the genetic divergence between strains and to find molecular markers more appropriate for the characterization of new strains.

In conclusion, shiitake mushroom yield on Eucalyptus sawdust media is dependent on strain and substrate and their interactions irrespective of controlled or semi-controlled cultural conditions. However, individual mushroom weight was dependent on strain but not the substrate. In our study, strain LE6 would be the best overall strain for controlled or semi-controlled environments.

Acknowledgments The FAPEMIG (Fundação de Amparo a Pesquisa do Estado de Minas Gerais), CAPES (Coordenação de Aperfeiçoamento de Pessoal de Nível Superior) and CNPq (Conselho Nacional de Desenvolvimento Científico e Tecnológico) are acknowledged for financial support.

\section{References}

Boyle D (1998) Nutritional factors limiting the growth of Lentinula edodes and other white-rot fungi in wood. Soil Biol Biochem 30:817-823
Bruhn JN, Mihail JD (2009) Forest farming of shiitake mushrooms: aspects of forced fruiting. Bioresour Technol 100:5973-5978

Dias ES, Zied DC, Rinker DL (2013) Physiologic response of Agaricus subrufescens using different casing materials and practices applied in the cultivation of Agaricus bisporus. Fungal Biol 117:569-575

Edwards K, Johnstone C, Thompson C (1991) A simple and rapid method for the preparation of genomic plant DNA for PCR analysis. Nucleic Acids Res 19:1349

Gbolagade JS, Fasid IO, Ajayi EJ, Sobowale AA (2006) Effect of physico-chemical factors and semi-synthetic media on vegetative of Lentinus subnudus (Berk.), and edible mushroom from Nigeria. Food Chem 99:742-747

Jennings DH (1995) The physiology of fungal nutrition. Cambridge University Press, Cambridge

Jiang T, Wang Q, Xu S, Jahangir MM, Ying T (2010) Structure and composition changes in the cell wall in relation to texture of shiitake mushrooms (Lentinula edodes) stored in modified atmosphere packaging. J Sci Food Agric 90:742-749

Mata G, Savoie JM (1998) Extracellular enzyme activities in six Lentinula edodes strains during cultivation in wheat straw. World J Microbiol Biotechnol 14(4):513-519

Nikita VE, Tsivileva OM, Pankratov AN, Bychkov NA (2007) Lentinula edodes biotechnology - from lentinan to lectins. Food Technol Biotechnol 45:230-237

Philippoussis A, Diamantopoulou P, Israilides C (2007) Productivity of agricultural residues used for the cultivation of the medicinal fungus Lentinula edodes. Int Biodeter Biodegr 59(3):216-219

Rinker DL (1991) The influence of heat treatment, genotype and other cultural practices on the production of shiitake mushrooms on sawdust. Mushroom Sci XIII:497-502

Royse DJ, Sanchez-Vazquez JE (2001) Influence of substrate woodchip particle size on shiitake (Lentinula edodes) yield. Bioresour Technol 76(3):229-233

Royse DJ, Sanchez-Vazquez JE (2003) Influence of precipitated calcium carbonate $\left(\mathrm{CaCO}_{3}\right)$ on shiitake (Lentinula edodes) yield and mushroom size. Bioresour Technol 90(2):225-228

Zervakis G, Philippoussis A, Loannidou S, Diamantopoulus P (2001) Mycelium growth kinetics and optimal temperature conditions for the cultivation of edible mushroom species on lignocellulosic substrates. Folia Microbiol 46:231-234

Zhang R, Hu D, Zhang J, Zuo X, Jiang R, Wang H, Ng TB (2010) Development and characterization of simple sequence repeat (SSR) markers for the mushroom Flammulina velutipes. J Biosci Bioeng 110:273-275

Zied DC, Savoie JM, Pardo-Giménez A (2011) Soybean the main nitrogen source in cultivation substrates of edible and medicinal mushrooms. Soybean and nutrition. Tech Open Access Publisher, Rijeka, pp 433-452 